\title{
Kutanöz sarkoidozlu 27 hastanın retrospektif analizi
}

\author{
Retrospective analysis of 27 patients with cutaneous sarcoidosis
}

\section{Kenan Aydoğan, Yasemin Aydın, Șaduman Balaban Adım*, Ișıl Tilki Günay, Hayriye Sarıcaoğlu, Emel Bülbül Bașkan, Șükran Tunalı}

Uludağ Üniversitesi Tıp Fakültesi, Deri ve Zührevi Hastalıklar Anabilim Dalı ve *Patoloji Anabilim Dalı, Bursa, Türkiye

Özet

Amaç: Sarkoidoz; nedeni bilinmeyen, nonkazeifiye granülomatöz histopatolojisi olan, özellikle akciğer, retiküloendotelyal sistem, göz ve deriyi tutan multisistemik bir hastalıktır. Tüm sarkoidozlu olgularda deri tutulumu \%9-37 oranında bildirilirken, sadece deri tutulumu \%5,4-13,8 arasındadır. Bu retrospektif çalışmada amaç sarkoidozlu hastalarımızın klinikopatolojik özelliklerini ve kutanöz sarkoidoz ile sistemik sarkoidoz arasındaki ilişkiyi incelemektir.

Gereç ve Yöntem: 2005-2011 tarihleri arasında klinik ve patolojik olarak kutanöz sarkoidoz tanısı almış 27 hastanın tıbbi kayıtları geriye dönük olarak incelendi.

Bulgular: Hastaların 22'si kadın, 5'i erkekti. Yaş ortalamaları 45 idi (12-69 arası). Hastalık süresi 1 ay-5 yıl (ort. 1,5 yıl) arasında değişmekteydi. Hastaların \%30'unda sadece deri tutulumu, 19'unda (\%70) ekstrakutanöz tutulum vardı. Sarkoidoz spesifik deri lezyon tiplerinin dağılımı plak (12), nodül (10), papül (6), lupus pernio (4), makülopapül (1) şeklindeydi ve lezyonların en çok yerleştiği alanlar baş-boyun bölgesi idi. Bir hastada eritema nodozum (EN) vardı. Sadece deri tutulumu olan 8 hastada topikal ve sistemik kortikosteroid, ekstrakutanöz tutulumu olan hastalarda sistemik, topikal ve intralezyoner kortikosteroid, metotreksat kullanıldı. Olgularımızın çoğunda 2 yıllık takip döneminde deri lezyonu düzelirken, \%33'ünde nüks gözlendi.

Sonuç: Kutanöz tutulum sistemik hastalığın ilk bulgusu olarak ortaya çıkabilir. Çalışma verilerimize göre olgularımızın \%30'u sadece deri tutulumu ile karakterizedir. Kutanöz sarkoidal granülomlu hastalarda sistemik hastalık bulguları da eşlik edebilmektedir. Bu yüzden dermatoloji bölümüne başvuran tüm kutanöz sarkoidozlu hastalarda sistemik tutulumun araştıılması gerekir. (Türkderm 2013; 47: 148-54)

Anahtar Kelimeler: Kutanöz sarkoidoz, sistemik sarkoidoz, nonkazeifiye granülom

Summary

Background and Design: Sarcoidosis is a multisystem disorder of unknown etiology, characterized by noncaseating granulomas involving especially the lungs, reticuloendothelial system, eyes and skin. Although skin involvement has been reported in 9-37\% of patients with sarcoidosis, isolated skin involvement has been reported in only 5.4\%-13.8\% of the cases. The purpose of this retrospective study was to evaluate the clinical and histopathological characteristics of patients with sarcoidosis and the relationship of cutaneous sarcoidosis with systemic sarcoidosis.

Materials and Methods: Case records and histopathological files of 27 patients who were diagnosed with cutaneous sarcoidosis in our Dermatology and Venereology Department from 2005 to 2011 were retrospectively reviewed.

Results: A total of 27 patients (22 female and 5 male) with a mean age 45 (12-69) years were evaluated. The mean duration of the

Yazışma Adresi/Address for Correspondence: Dr. Kenan Aydoğan, Uludağ Üniversitesi Tip Fakültesi, Deri ve Zührevi Hastallklar Anabilim Dall, Bursa, Türkiye Tel.: +90 2242950712 E-posta: aydogank@uludag.edu.tr Geliş Tarihi/Received: 31.08.2012 Kabul Tarihi/Accepted: 21.01.2013 
disease was 1.5 years ( 1 month to 5 years). In 30\% of patients, only skin lesions were found, and 19 patients (70\%) had extracutaneous involvement. The distribution of specific types of skin lesions was plaque (12), nodules (10), papules (6), lupus pernio (4) and maculopapular rashes (1). The most common localization of the lesions was the head and neck region. One patient had an erythema nodosum lesion. Topical and systemic corticosteroids were used in eight patients with isolated skin lesions. Systemic, topical and intralesional corticosteroids and methotrexate were used in patients with extracutaneous involvement. In most of the patients, skin lesions were improved within 2-years follow-up period. Relapse was observed in 33\% of patients.

Conclusion: Cutaneous involvement can occur as the first sign of a systemic disease. According to our study results, $30 \%$ of our cases were characterized with isolated skin involvement. The signs of a systemic disease may accompany cutaneous sarcoidosis. Therefore, all patients presenting to the dermatology departments with cutaneous sarcoidosis require investigations for systemic sarcoidosis. (Turkderm 2013; 47: 148-54)

Key Words: Cutaneous sarcoidosis, systemic sarcoidosis, noncaseating granuloma

\section{Giriş}

Sarkoidoz, nedeni tam olarak bilinmeyen ve genel olarak akciğerleri, periferik ve mediastinal lenf nodlarını, karaciğer, dalak, deri, göz ve parotis bezini etkileyebilen, multisistemik, granülomatöz bir hastalıktır . Sarkoidoz kadınlarda daha sık görülür ve sıklığı yaşam boyu 25-35 yaş ile 45-55 yaş aralığında zirve yapar². Sarkoidoz prevalansı, lezyon tipi, şiddeti, ekstrakutanöz tutulum gibi özellikleri ülkelere, farklı etnik gruplar ve cinsiyete göre değişkenlik göstermektedir3 ${ }^{3}$ Tüm dünyada yaygın olarak görülen bu hastalığın sıklığı, kış ve ilkbahar mevsiminde artış göstermektedir 4 . Tüm sarkoidoz vakalarının yaklaşık \%25'inde (\%937) deri tutulumu gözlenmekte iken hastaların \%5,4-13,8'inde sadece deri tutulumu gözlenmektedir1,5,6. Kutanöz sarkoidoz lezyonları özgün ve özgün olmayan olmak üzere iki sınıfta incelenir. Özgün lezyonlar sarkoidal granülomlar, özgün olmayan lezyonlar reaktif süreçlerdir. Özgün lezyonlar; makülopapüller, nodüller, plaklar, subkutan nodüller, infiltratif skarlar ve lupus pernio olarak; özgün olmayan lezyonlar eritema nodozum (EN), eritema multiforme, kalsifikasyon ve prurigo olarak görülür7. Sarkoidoz tanısı, uyumlu klinik ve radyolojik bulgulara ek olarak bir veya daha fazla dokuda nonkazeifiye granülom yapısının gösterilmesi ve diğer granülom yapan nedenlerin dışlanmasıyla konur8. Sarkoidoz büyük taklitçi hastalıklardan biridir. Deri belirtilerinin birçok dermatolojik hastalıkla ayııcı tanı içine girmesi nedeniyle tanı için öncelikle akla gelmelidir. Bu retrospektif çalısmanın amacı sarkoidozlu hastalarımızın klinikopatolojik özelliklerini irdelemek, kutanöz sarkoidozlu hastaların sistemik tutulum açısından değerlendirmektedir.

\section{Gereç ve Yöntem}

Çalışmaya Ocak 2005 ve Mayıs 2012 yılları arasında tetkik edilen, klinik ve histopatolojik olarak sarkoidoz tanısı almış toplam 27 hasta dahil edildi. Hasta verileri epikriz ve hasta dosyalarından geriye dönük olarak incelendi ve hastaların epidemiyolojik, klinik ve histopatolojik özellikleri ortaya konuldu. Çalışmaya Klinik Araştırmalar Etik Kurulu 2012-6/14 no'lu onayı ile başlandı.

Hastaların demografik bilgileri, fizik muayene bulguları, lezyonların morfolojisi, hastalık süresi, ekstrakutanöz tutulum varlığı, hastalığın evresi, tedavileri ve tedaviye cevapları kaydedildi. Eritrosit sedimentasyon hızı (ESH), akciğer grafisi, tüberkülin deri testi, karaciğer fonksiyon testleri (KCFT), böbrek fonksiyon testleri, tam kan sayımı, serum ve idrar kalsiyumu, anjiotensin dönüştürücü enzim (ACE) değerlendirildi. Histopatolojik olarak kazeifikasyonun izlenmediği granülom yapıları, granülomların yerleşim yerleri, lenfosit, dev hücre, yabancı cisim, asteroid cisimler ve kalsifikasyonlar irdelendi. Sarkoidoz tanısı konulurken; klinik, radyolojik ve histopatolojik özellikler esas alındı. Olgular akciğer grafilerine göre beş evre olarak sınıflandırılı. Evre 0; normal, Evre 1; bilateral hiler lenfadenopati, Evre 2; bilateral hiler lenfadenopati ve parankim infiltrasyonu, Evre 3; parankim infiltrasyonu, Evre 4; bal peteği görünüm ve fibrozis9.

\section{Bulgular}

1. Dermatolojik ve fizik muayene bulguları: Hastaların 22'si kadın, 5'i erkekti. Yaş ortalamaları 45 idi (12-69 arası). Hastalık süresi 1 ay-5 yıl (ort. 1,5 yıl) arasında değişmekteydi. Yirmi hastanın (\%74) ilk başvuru şikayeti deri belirtileri nedeni ile dermatoloji polikliniğine olurken, 7 hastada (\%26) göğüs hastalıkları, göz hastalıkları ve göğüs cerrahisi bölümünden sarkoidoz tanısı konulduktan sonra konsültasyon ile değerlendirilmişti. Sarkoidoza spesifik deri lezyon tiplerinin dağılımı; 12 hastada (\%44) plak, 10 hastada (\%37) nodül, 6 hastada $(\% 22,2)$ papül, 4 hastada $(\% 14,8)$ lupus pernio, 1 hastada $(\% 3,7)$ makülopapül şeklindeydi (Şekil 1a, 1b). iki hastada $(\% 7,4)$ papül ve plak birlikteliği, 3 hastada (\%11) plak ve nodül birlikteliği gözlendi. Lezyonlar en sık olarak 16 hastada (\%59) baş-boyun bölgesinde iken, 8 hastada $(\% 29,6)$ gövdede, 12 hastada (\%44) alt ekstremitede, 12 hastada (\%44) üst ekstremitede gözlendi. On üç hastada (\%48) birden fazla anatomik bölge tutulumu mevcuttu. Bir hastada EN vardı. Hastaların 8'inde (\%30) sadece deri tutulumu, 19'unda (\%70) ekstrakutanöz tutulum vardı (Tablo 1). Sadece deri tutulumu olan hastaların lezyon tiplerinin dağılımı nodül (3), plak (4), papül (1), makülopapül (1) şeklindeydi. Ekstrakutanöz bulguları birincil şikayetleri olan, konsültasyon ile değerlendirdiğimiz 7 hastanın 2 (\%28)'sinde plak, 2 (\%28)'sinde papül, 2 (\%28)'sinde nodül ve 1 (\%14)'inde lupus pernio gözlendi.

2. Histopatolojik incelemeler: Yirmi yedi hastanın 35 adet deri biyopsisi (6 olguda 2 adet, 1 olguda 3 adet ve diğer olgularda birer adet) histopatolojik olarak incelendi ve spesifik deri lezyonu olan 
tüm hastalarda sarkoidoza özgü tipik nonkazeifiye granülom yapısı gözlendi. Histokimyasal boyamalar ile mikobakteri veya fungal organizmalar ekarte edildi. Histopatolojik bulgular gösterildi (Tablo 2). Histopatolojik incelemede, granülom yapıları 24 hastada (\%88) yüzeyel dermiste, 23 hastada (\%85) derin dermiste, 12 hastada
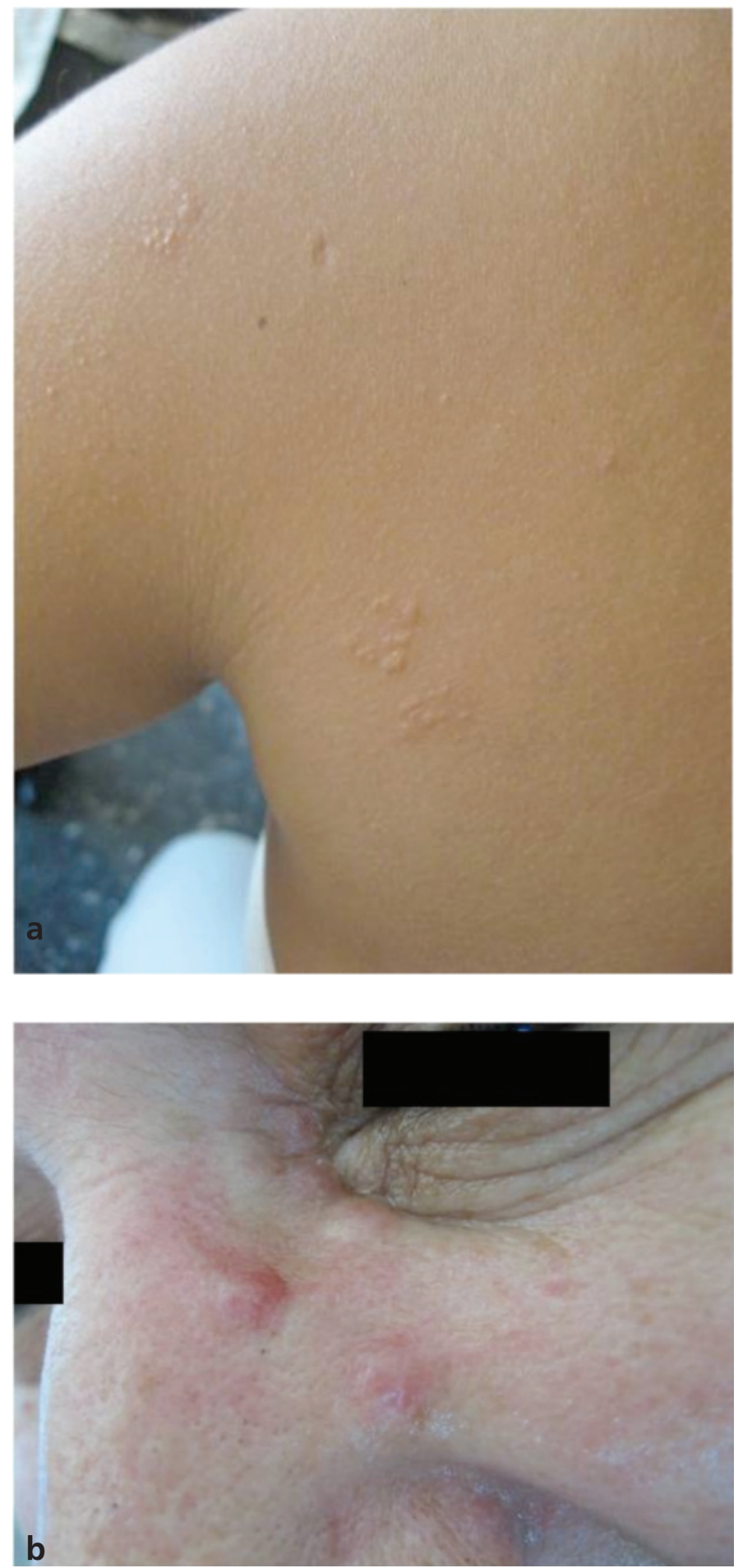

Şekil 1. Klinik görünümler. a) Papül formu, b) Lupus pernio
(\%44) ise subkutan yağ dokuda gözlendi. Fibrinoid nekroz 8 hastada $(\% 29,6), 6$ hastada (\%22) asteroid cisim, 1 hastada $(\% 3,7)$ yabanc cisim, 2 hastada $(\% 7,4)$ kalsifikasyon, 26 hastada $(\% 96,2)$ dev hücre, 26 hastada $(\% 96,2)$ lenfosit ve 5 hastada $(\% 18,5)$ fibrozis gözlendi (Şekil 2a, 2b)

3. Radyolojik bulgular: Ekstrakutanöz tutulumlar radyolojik incelemeler, bronkoskopi, mediastinoskopi, periferik lenf bezi biyopsisi ve akciğer wedge rezeksiyonu ile saptanmıştır. İki hastada mediastinoskopi, 2 hastada akciğer wedge rezeksiyon, 13 hastada bronkoskopi yapılmış olup bu işlemler sarkoidoz tanısını koymak veya desteklemek; ayırıc tanı içine giren hastalıkları dışlamak amacıyla yapılmıştır. Üç hastada aksiller bölgede, 1 hastada servikal bölgede, 1 hastada servikal ve aksiller bölgede lenfadenopati saptanmış, 2 hastaya periferik lenf nodu biyopsisi yapılarak klinik ve radyolojik bulgularla birlikte tanı konulmuştur. Hastaların hepsi akciğer grafisi ile değerlendirilirken, 24 hastada toraks bilgisayarlı tomografi istenmiştir. Dokuz hastada el ve ayak kemik grafileri istenerek patoloji saptanmamıştır. Radyografik evrelemede 27 hastanın 8 (\%29,6)'inde evre 0, $2(\% 7,4)^{\prime}$ sinde evre 1, $15(\% 55,5)^{\prime}$ inde evre 2, 1 'inde evre 3 $(\% 3,7), 1$ 'inde evre $4(\% 3,7)$ olarak belirlendi (Tablo 3).

4. Laboratuvar incelemeleri: On dört hastaya yapılan tüberkülin deri testi 11 hastada anerjik olarak saptandı. Tüm hastalarda tam kan sayımı, ESH, KCFT, böbrek fonksiyon testleri değerlendirilmiş olup 20 hastada serum kalsiyum düzeyi, 16 hastada serum idrar kalsiyum düzeyi, 16 hastada ACE düzeyi değerlendirildi. Laboratuvar tetkiklerinde 15 hastada (\%55) ESH yüksekliği, 2 hastada $(\% 7,4)$ lökositoz, 7 hastada (\%25) anemi, 2 hastada $(\% 7,4)$ KCFT'inde yükseklik, 12 hastada $(\% 75)$ ACE yüksekliği, 5 hastada (\%31) 24 saatlik idrar kalsiyumunda yükseklik, 4 hastada (\%20) serum kalsiyum yüksekliği saptandı (Tablo 4).

5. Tedavi: Sadece deri tutulumu olan 8 hastada topikal ve sistemik kortikosteroid, ekstrakutanöz tutulumu olan hastalarda sistemik, topikal ve intralezyoner kortikosteroid, metotreksat kullanıldı. Olgularımızın çoğunda 2 yıllık takip döneminde deri lezyonu düzelirken, \%33'ünde nüks gözlendi.

\section{Tartışma}

Günümüzde kabul edilen son etyopatogenetik mekanizmaya göre sarkoidoz genetik olarak yatkınlığı bulunan bir kişide henüz tam olarak tanımlanamamış çevresel bir antijenik uyarana maruziyet ile gelişen kronik bir immünolojik yanıt sonucunda oluşmaktadır. Sarkoidozda granülomatöz inflamasyon alanlarında Th1 aracılı immünolojik yanıt belirginken periferal immün yanıtlar paradoks olarak baskılanmıştır ${ }^{10}$. Literatürlerde yaş ortalaması 41-49 yaş aralığında, kadın/erkek oranı 0,6-2,7 olarak belirtilmiştir1,11-13. Bizim hasta serimizde yaş ortalamas 45 ve kadın/erkek oranı 3,1 olarak literatür ile uyumlu bulundu. Literatürde az sayıda bildirilen çocuk olgular mevcuttur. Çocukluk çağı sarkoidozu nadir görülür; erken başlangıçlı ve geç başlangıçlı olmak 


\section{Tablo 1. Kutanöz sarkoidozlu hastaların klinik özellikleri}

\begin{tabular}{|c|c|c|}
\hline Özellikler & Hasta sayısı & Yüzde (\%) \\
\hline \multicolumn{3}{|l|}{ Cinsiyet } \\
\hline Kadın & 22 & 81 \\
\hline Erkek & 5 & 19 \\
\hline \multicolumn{3}{|l|}{ Lezyon bölgesi } \\
\hline Baş-boyun & 16 & 59 \\
\hline Gövde & 8 & 29,6 \\
\hline Alt ekstremite & 12 & 44 \\
\hline Üst ekstremite & 12 & 44 \\
\hline$\geq 2$ bölge & 13 & 48 \\
\hline \multicolumn{3}{|l|}{ Lezyon morfolojisi } \\
\hline Plak & 12 & 44 \\
\hline Nodül & 10 & 37 \\
\hline Papül & 6 & 22,2 \\
\hline Lupus pernio & 4 & 14,8 \\
\hline Makülopapül & 1 & 3,7 \\
\hline \multicolumn{3}{|l|}{ illk başvuru } \\
\hline Kutanöz & 20 & 74 \\
\hline Ektrakutanöz & 7 & 26 \\
\hline \multicolumn{3}{|l|}{ Ektrakutanöz bulgu } \\
\hline Akciğer & 19 & 70,4 \\
\hline Oftalmik & 2 & 7,4 \\
\hline Gastrointestinal & 3 & 11,1 \\
\hline
\end{tabular}

üzere iki farklı formu vardır. Prognoz çocuklarda erişkin hastalara oranla daha iyi olmakla birlikte çok küçük yaşlarda semptomatik multisistem tutulumları daha ağır seyreder ${ }^{14}$. Bizim çalışmamızda da sarkoidoz tanısı konulan 12 yaşında bir kız çocuğunda sistemik tutulum saptanmadı ve topikal steroid verilerek tama yakın yanıt elde edildi.

Yapılan çalışmalarda hastalık süresi 0,5 ay-40 yıl2,4,11-13 olarak belirtilirken bizim çalışmamızda ort. 1,5 yıl olarak saptanmıştır. Sarkoidozun taklitçi bir hastalık olması, klinik görünümünün çeşitlilik göstermesi ve tanı için histopatolojik ve radyolojik değerlendirme gerektirmesi ve genellikle lezyonların asemptomatik olması nedeniyle hastalığın başlangııından tanı koymasına kadar geçen süre değişkenlik göstermektedir.

Tüm sarkoidozlu olgularda kutanöz tutulum \%9-37 arasında değişmektedir15. Bizim çalışmamızda bu oran literatür ile uyumlu olarak \%30 olarak saptanmıştır. Makülopapüler lezyonlar en sık görülen özgün kutanöz sarkoidoz lezyonlarıdır. Lezyonlar sıkııkla baş, boyun, sırt, ekstremiteler ve nadiren oral kavitede yerleşirler ${ }^{16}$. En sik baş ve boyun bölgesinde $(\% 41,2-\% 68)^{4,12}$, ülkemizde Güler ve ark.2 yaptığı çalışmada en sık alt ekstremitede (\%60), Marcoval ve ark.17 yaptığı çalışmada en sık birden fazla bölgede görüldüğü bildirilmiştir. Bizim çalışmamızda \%59 oranında en sık lezyon bölgesi literatür ile uyumlu olarak baş-boyun bölgesi olarak gözlendi. Deri lezyon tiplerine göre değerlendirilen çalışmalarda Marcoval ve ark. ${ }^{17}$ en sık plak tip (\%36), Mangas ve ark. ${ }^{1}$ en sık nodüloplak (\%31), Özşeker ve ark. ${ }^{18}$ en sık subkutan nodül (\%23), Güler ve ark. ${ }^{2}$ en sık papül, plak ve nodül (\%33,3), Chong ve ark. ${ }^{12}$ en sık papül ve nodül (\%72), Collin ve ark. ${ }^{11}$ en sık papül (\%44), Jung ve ark. ${ }^{4}$ en sik noduloplak formu $(\% 41,2)$ görüldüğünü bildirilmiştir. Bizim çalışmamızda en sık olarak

Tablo 2. Histopatolojik Bulgular*

\begin{tabular}{|c|c|c|c|c|c|}
\hline Granülom Özellikleri & Hafif & Orta & Şiddetli & Total & $\%$ \\
\hline Yüzeyel dermis & 10 & 7 & 13 & 24 & $\% 88$ \\
\hline Derin dermis & 7 & 6 & 15 & 23 & $\% 85$ \\
\hline Subkutan doku & 7 & 3 & 2 & 12 & $\% 44$ \\
\hline Fibrinoid nekroz & 8 & - & - & 8 & $\% 29,6$ \\
\hline Dev hücre & 16 & 7 & 6 & 26 & $\% 96,2$ \\
\hline Lenfosit & 5 & 22 & 6 & 26 & $\% 96,2$ \\
\hline Yabancı cisim & - & 1 & - & 1 & $\% 3,7$ \\
\hline Fibrozis & 4 & 1 & - & 5 & $\% 18,5$ \\
\hline Asteroid cisim & 5 & 1 & - & 6 & $\% 22$ \\
\hline Kalsifikasyon & 2 & - & - & 2 & $\% 7,4$ \\
\hline
\end{tabular}

*27 hastada 35 histopatolojik kesit incelemesi 
12 hastada (\%44) plak formu gözlenirken, en az olarak 1 hastada $(\% 3,7)$ makülopapül formu gözlendi. Bir hastada EN gözlendi fakat özgün olmayan deri bulgusu olarak kabul edildiği için sınıflandırmaya dahil edilmedi.

Sarkoidozda bazı tip kutanöz lezyonlar prognostik öneme sahiptir. Lupus pernio, plak ve subkutanöz sarkoidoz lezyonlarında sistemik tutulum daha sık, daha şiddetli ve daha kronik seyretmektedir3,7,17,19
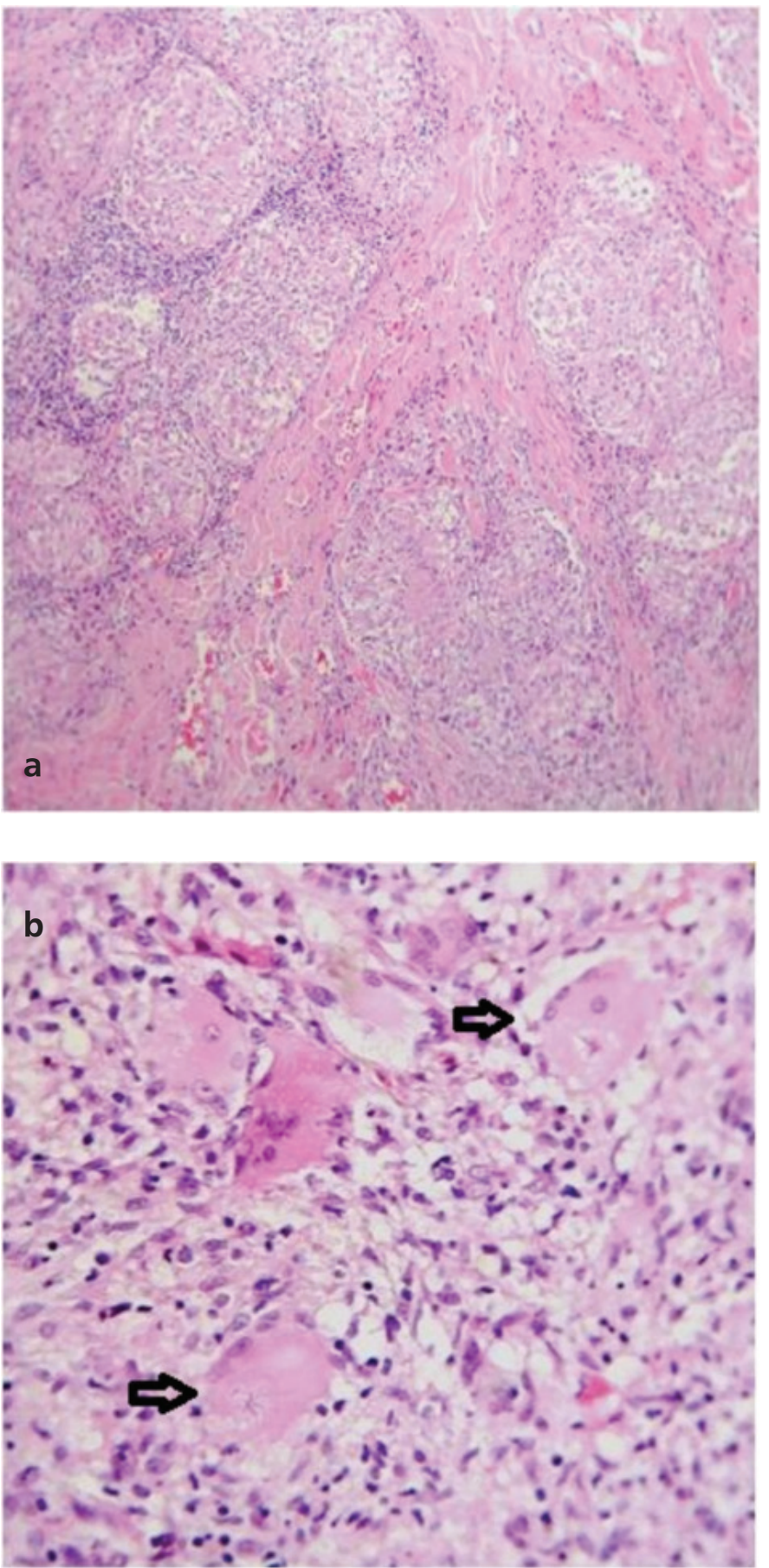

Şekil 2. Histopatolojik özellikler a) Kompakt Granülomlar, b) Asteroid cisimler (ok ile işaretli)
Özellikle bu sistemik tutulumlar üst solunum yolu, akciğer, kemik ve bilateral hiler LAP üzerinde yoğunlaşmaktadır ${ }^{19}$. Ancak deri tutulumunun prognoza etkisi konusunda henüz bir görüş birliğ yoktur16,20. Olive ve ark. ${ }^{21}$ çalışmasında spesifik lezyonlu olgularda progresyon, EN'li olgulara göre daha fazla görülmüş olmakla birlikte, deri tutulumu olmayan sarkoidoza göre fark bulunmamıştır. Keller22, beş yıllık serisinde tüm sarkoidozlulara göre kutanöz sarkoidozluların prognozunun benzer olduğunu bildirmiştir. Sarkoidoz lezyonlarının tipine göre sistemik tutulum açısından değerlendirildiğimizde lupus pernio olan 4 hastanın tamamında sistemik tutulum saptadık. íki hasta (\%50) Evre 1, 1 hasta (\%25) Evre 2, 1 hasta (\%25) evre 4 olarak takip edilmekteydi. Evre 0 olan 8 hastada en sık plak formu gözlendi. Evre 3 olan bir hastada papül ve plak birlikteliği gözlendi. Evre 2 olan 15 hastada en sık plak ve nodül formu gözlendi. Sistemik tutulum olan veya olmayan hastalarda en sık plak formu gözlenirken lupus pernio olan hastalarımızın tamamında sistemik tutulum saptandı. Deri lezyonları ve sistemik tutulum açısından değerlendirdiğimizde 19 ekstrakutanöz tutulum olan hastanın 9'unda plak, 7'sinde nodül, 3'ünde papül, 4'ünde lupus pernio saptadık.

Tablo 3. Kutanöz sarkoidozlu hastaların radyolojik özellikleri

\begin{tabular}{|l|c|c|}
\hline Özellikler & Hasta sayısı & Yüzde (\%) \\
\hline Akciğer grafisi bulguları & & \\
Evre 0 & 8 & 29,6 \\
Evre 1 & 2 & 7,4 \\
Evre 2 & 15 & 55,5 \\
Evre 3 & 1 & 3,7 \\
Evre 4 & 1 & 3,7 \\
\hline
\end{tabular}

\section{Tablo 4. Kutanöz sarkoidozlu hastaların laboratuvar} bulguları

\begin{tabular}{|l|c|c|}
\hline Laboratuar parametreleri & Hasta sayısı & Hasta yüzdesi \\
\hline Lökositoz & 2 & $\% 7,4$ \\
\hline Anemi & 7 & $\% 25$ \\
\hline ESH yüksekliği & 15 & $\% 55,5$ \\
\hline $\begin{array}{l}\text { Hiperkalsemi } \\
\text { Serum } \\
24 \text { saatlik idrar }\end{array}$ & $4^{*}$ & $\% 20$ \\
\hline ACE yüksekliği & $5^{\square}$ & $\% 31$ \\
\hline KCFT yüksekliği & $12^{\text {口 }}$ & $\% 75$ \\
\hline
\end{tabular}

ESH: Eritrosit sedimentasyon hızı ACE: Anjiotensin dönüştürücü enzim KCFT: Karaciğer fonksiyon testi * 20 hastada bakılmışıı

-16 hastada bakılmıştır 
Çalışmamızda tüm olgularda sarkoidoza özgü tipik granülom yapısı gözlendi. Yapılan histopatolojik incelemede, granülomların hangi alanlarda yoğunlaştığı, nekroz içerip içermediği, Asteroid cisim, kalsifikasyon, yabancı cisim, dev hücre, lenfosit ve fibrozisin varlığı araştırıldı. Granülom yapıları 24 (\%88)'ünde yüzeyel dermiste, 23 (\%85)'ünde derin dermiste, 12 (\%44)'sinde ise subkutan yağ dokuda gözlendi. Yirmi yedi hastaya ait olan 35 adet biyopsi preparatında; granülomlar 3 hastada yüzeyel dermiste gözlenmezken, derin dermis ve subkutan yağ dokuda gözlenmiştir. ỉki hastada ise granülomlar yüzeyel dermis ve derin dermiste gözlenmezken sadece subkutan yağ dokuda gözlenmiştir. Yüzeyel dermisin incelendiği olgularda granülomların gözlenmemesi sarkoidozu ekarte ettirmez. Bu nedenle sarkoidozdan şüphenilen durumlarda biyopsinin derin dermis ve subkutan yağ dokuyu kapsayacak şekilde derin alınması gereklidir. Histopatolojik incelemede Asteroid cisim, kalsifikasyon, fibrozis ve yabancı cisim daha az oranda görüldü. Fibrinoid nekroz 8 hastada $(\% 29,6)$ gözlenirken; bu oran Jung ve ark. ${ }^{4}(\% 41)$, Güler ve ark. ${ }^{2}(\% 6,6)$, Mangas ve ark. ${ }^{1}$ $(\% 12,5)$ olarak belirtilmiştir. Çalışmamızda Asteroid cisim 6 hastada (\%22) gözlendi. Bu oran; Jung ve ark. ${ }^{4}$ çalışmasında \%17, Güler ve ark. ${ }^{2}$ çalışmasında \%13,3, Mangas ve ark. ${ }^{1}$ çalışmasında \%9 oranında bildirilmiştir. Dev hücre $26(\% 96,2)$ hastada gözlenirken; Jung ve ark. ${ }^{4}$ $\% 70$, Güler ve ark.2 \%86,6 bildirdiği oranlardan daha yüksek olarak bulundu. Bu sonuçlarla klinik bulgularda olduğu gibi histopatolojik özelliklerinde ırksal ve genetik faktörlere bağlı olarak çeşitlilik gösterdiği anlaşılmaktadır.

Klinik şüphe ve karakteristik histolojik bulgular tanı için önemlidir20. Sarkoidozun klinik olarak tanısı lezyonların polimorfik olma özelliği ve taklitçi hastalık olması nedeniyle güçtür. Ayırıcı tanıda nekrobiyozis lipoidika, lenfoma, granülomatöz rozase, lupus vulgaris, lepra, sifiliz, mikozis fungoides, derin fungal enfeksiyonlar, yabancı cisim granülomları bulunmaktadır15,23. Bu nedenle biyopsi materyallerinde ve laboratuvar tetkiklerinde infeksiyon etkenleri dışlanmalı, sarkoidal granülomlar diğer granülom yapan hastalıklardan ayırt edilmelidir.

Kutanöz sarkoidozda tedavi genelde topikal, intralezyonel veya sistemik steroidler ile yapılır. Kutanöz sarkoidoz tedavisinde ayrıca tetrasiklin türevleri, antimalaryal ilaçlar (klorokin ve hidroksiklorokin), metotreksat, biyolojik ajanlar(infliksimab,etanersept ve adalimumab), izotretinoin, pentoksifilin, siklosporin A, topikal takrolimus ile de başarılı sonuçlar gözlenmiştir3,4,7,11,12,15,24-26. Sadece deri tutulumu olan 8 hastada topikal ve sistemik kortikosteroid, ekstrakutanöz tutulumu olan hastalarda sistemik, topikal ve intralezyoner kortikosteroid kullandık. Ekstrakutanöz tutulumu olan kortikosteroid kullanımının kontrendike olduğu bir hastada metotreksat ve intralezyoner steroid tedavisi kullandık. Olgularımızın çoğunda 2 yıllık takip döneminde deri tutulumu olan 2 hastada $(\% 7,4)$, ekstrakutanöz tutulumu olan 7 hastada $(\% 25,9)$ nüks gözlendi. Jung ve ark. ${ }^{4}$ yaptığı çalışmada tedavi sonrası \%12 gibi daha düşük oranda nüks gözlenmiş olup bu durum ekstakutanöz tutulumun bizim çalışmamıza göre daha az olmasından kaynaklanabileceğini düşündürmektedir.

Kutanöz sarkoidoz tanısı için öncelikle şüphelenmek gerekir. Tanı için ayrıntılı bir fizik muayene yapılmalı; klinik, histopatolojik, radyolojik ve laboratuvar bulguları eşliğinde tanıya gidilmelidir. Kutanöz sarkoidozlu hastalarda sistemik tutulum açısından taranmalı ve takibe alınmalıdır.

\section{Kaynaklar}

1. Mangas C, Fernández-Figueras MT, et al: Clinical spectrum and histological analysis of 32 cases of specific cutaneous sarcoidosis. J Cutan Pathol 2006;33:772-7.

2. Güler $E$, Gülüş Demirel $B$, Kontaş O: Kutanöz sarkoidozlu 15 hastanın geriye dönük analizi. Turk J Dermatol 2011;5:66-70.

3. Newman LS, Rose CS, Maier LA: Sarcoidosis. N Engl J Med 1997;336:122434.

4. Jung YJ, Roh MR: Clinical and histopathological analysis of specific lesions of cutaneous sarcoidosis in Korean patients. J Dermatolog Treat 2010;22:11-7.

5. Karaca N, Ertam I, Kılınç Karaarslan I, Kazandı AC, Dereli T: Çiçek aşısı skarı üzerinde gelişen bir sarkoidoz olgusu. Türk Dermatoloji Dergisi 2007;1:27-8.

6. Hunninghake G, Costabel $U$, Ando M, et al: Statement on sarcoidosis. Am J Respir Crit Care Med 1999;126:736.

7. Wolf K, Lowell AS, Katz I, et al: Fitzpatrick's dermatology in general Medicine. $7^{\text {th }}$ ed. New York: McGraw-Hill Co, 2008;1484-93.

8. Costabel U, Ohshimo S, Guzman J. Diagnosis of sarcoidosis. Curr Opin Pulm Med 2008;14:455-61.

9. No authors listed: Statement on sarcoidosis. Joint Statement of the American Thoracic Society (ATS), the European Respiratory Society (ERS) and the World Association of Sarcoidosis and Other Granulomatous Disorders (WASOG) adopted by the ATS Board of Directors and by the ERS Executive Committee, February 1999. Am J Respir Crit Care Med 1999;160:736-55.

10. Ali MM, Atwan AA, Gonzalez ML: Cutaneous sarcoidosis: updates in the pathogenesis. J Eur Acad Dermatol Venereol 2010;24:747-55.

11. Collin B, Rajaratnam $R$, Lim R, Lewis $H$ : A retrospective analysis of 34 patients with cutaneous sarcoidosis assessed in a dermatology department. Clin Exp Dermatol 2009;35:131-4.

12. Chong WS, Tan HH, Tan SH: Cutaneous sarcoidosis in Asians: a report of 25 patients from Singapore. Clin Exp Dermatol 2005;30:120-4.

13. Mahajan VK, Sharma NL, Sharma RC, Sharma VC: Cutaneous sarcoidosis: clinical profile of 23 Indian patients. Indian J Dermatol Venereol Leprol 2007;73:16-21.

14. Shetty AK, Gedalia A: Sarcoidosis: a pediatric perspective. Clin Pediatr (Phila) 1998;37:707-17.

15. English JC 3rd, Patel PJ, Greer KE: Sarcoidosis. J Am Acad Dermatol 2001;44:725-43.

16. Elgart ML: Cutaneous sarcoidosis: definitions and types of lesions. Clin Dermatol 1986;4:35-45.

17. Marcoval J, Mañá J, Rubio M: Specific cutaneous lesions in patients with systemic sarcoidosis: relationship to severity and chronicity of disease. Clin Exp Dermatol 2011;36:739-44.

18. Özşeker F, Bilgin S, Bayram Ü, et al: Sarkoidozda cilt tutulumu: 42 olgunun analizi. Solunum Hastalıkları 2007;18:1-6.

19. Mañá J, Marcoval J, Graells J, et al: Cutaneous involvement in sarcoidosis. Relationship to systemic disease. Arch Dermatol 1997;133:882-8.

20. Okamoto $\mathrm{H}$ : Epidermal changes in cutaneous lesions of sarcoidosis. Am J Dermatopathol 1999;21:229-33.

21. Olive KE, Katarina YP: Cutaneous manifestations of sarcoidosis. Relationships to other organ system involvement, abnormal laboratory measurements, and disease course. Arch Intern Med 1985;145:1811-4. 
22. Keller AZ: Anatomic sites, age attributes, and rates of sarcoidosis in U. S veterans. Am Rev Respir Dis 1973;107:615-20.

23. Fernandez-Faith E, McDonnell J: Cutaneous sarcoidosis: differential diagnosis. Clin Dermatol 2007;25:276-87.

24. Lodha S, Sanchez M, Prystowsky S: Sarcoidosis of the skin: a review for the pulmonologist. Chest 2009;136:583-96
25. Aksoy B, Aksoy HM, Akın O, Yüksekol i: Topikal takrolimus tedavisine çok iyi yanıt veren skar sarkoidozu. Türkderm 2011;45:219-21.

26. Badgwell C, Rosen T: Cutaneous sarcoidosis therapy updated. J Am Acad Dermatol 2007 ; 56:69-83. 